\title{
突発性難聴新鮮例の予後の推定
}

$\begin{array}{lrrrr}\text { 木村 } & \text { 裕毅・村田 } & \text { 清高·玉木 } & \text { 克彦・米井 } & \text { 潔 } \\ \text { 東 } & \text { 博二·飯田 } & \text { 覚·石川 } & \text { 雅洋・竹山 } & \text { 豊 } \\ \text { 横山 } & \text { 隆 } \cdot \text { 太田 } & \text { 文彦 } & & \end{array}$

\section{The Presumption of the Prognosis of the Fresh Cases in Sudden Deafness}

Hiroki Kimura, Kiyotaka Murata, Katsuhiko Tamaki, Kiyoshi Yonei, Hiroji Azuma, Satoru Iida, Masahiro Ishikawa, Yutaka Takeyama, Takashi Yokoyama and Fumihiko Ohta

(Kinki University School of Medicine)

The clinical data obtained on 97 ears of patients with sudden deafness who visited one week after onset were analyzed.

We tried to estimate the period for the management of sudden deafness. Multivariate analysis was used for statistical significance as over 0.8 at decision coefficient.

The required period of treatment of low frequency hearing loss was estimate to be 2.5 weeks, for 2 weeks at middle frequency hearing loss, and for 1.5 weeks at high frequency hearing loss, in the $\mathrm{T}$ group.

Key words: sudden deafness, statistical analysis, multivariate analysis, decision coefficient

はじめに

突発性難聴（以下, 突難と略す）の病因, 病 態は現在なお不明であり, 病態解明のため数多 (の病理組織学的検討5) 7)15)19), 電気生理学的 検討18)28), 臨床的検討がなされている1) 4)7) 9).

本疾患の病因, 病態が明らかにならないと, 予後についても確実なことは解らない。しかし， 臨床的事実から本疾患の予後を推定する試みも 多い。近年多变量解析を用いて初診時聴力, 聴 力型, 治療開始までの期間, メマイの有無, $\mathrm{CP}$ の有無などが突難の予後を左右する重要な 因子として報告されている315)25).

しかし，最終的な聴力つまり固定時聴力を治
療開始早々に推定することが，日常臨床におい て求められる事が多い。これは患者への説明に 際して最も重要な事柄である。我々は突難新鮮 例では，どれくらいの期間治療観察を行えば聴 力の経過観察のみで恥力の予後が大略推定出来 るかを知るために重回帰分析を使って検討し有 用な結果を得た。

\section{対 象}

昭和 50 年 5 月より, 昭和 61 年 12 月までの 11 年 間に近畿大学医学部耳鼻咽喉科外来を受診した 突難482例の5ち発症日を発症第一日として発 症後 7 日以内に当科を受診し, 聴力を 8 週間経 過観察することのできた97例，97耳を検討対象 
とした。なお，発症後の経過観察からメニエル 病と診断された症例や特発性両側進行性難聴が 疑われた症例, 他の原因, 誘因, 時間的な面か ら突難として疑わしい症例および，いわゆる低 音障害型突難と考えられる $1000 \mathrm{~Hz}$ 以下のみの 低音域の障害例を除外した。

〈年齢と性別〉

図 1 は，年齢と性別の分布を示した。男性 46 例 $(47.4 \%)$ ，女性51例 (52.5\%) で両者の間 には，カイ二乗検定にて有意差を認めなかった。

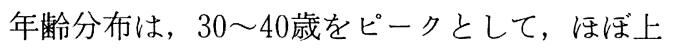
下に同様に分布している.

〈聴力型とメマイの有無〉

図 2 は, 聴力型と, メマイの有無を示した. メマイ有りが32例 $(33.0 \%)$, メマイ無しが 65 例 $(67.0 \%)$ であった. 聴力型では, 水平型 29 例 $(29.9 \%)$ ，低音障害型が22例 $(22.7 \%)$ ， ス ケールアウト型 21 例 $(21.6 \%)$, 高音障害型18

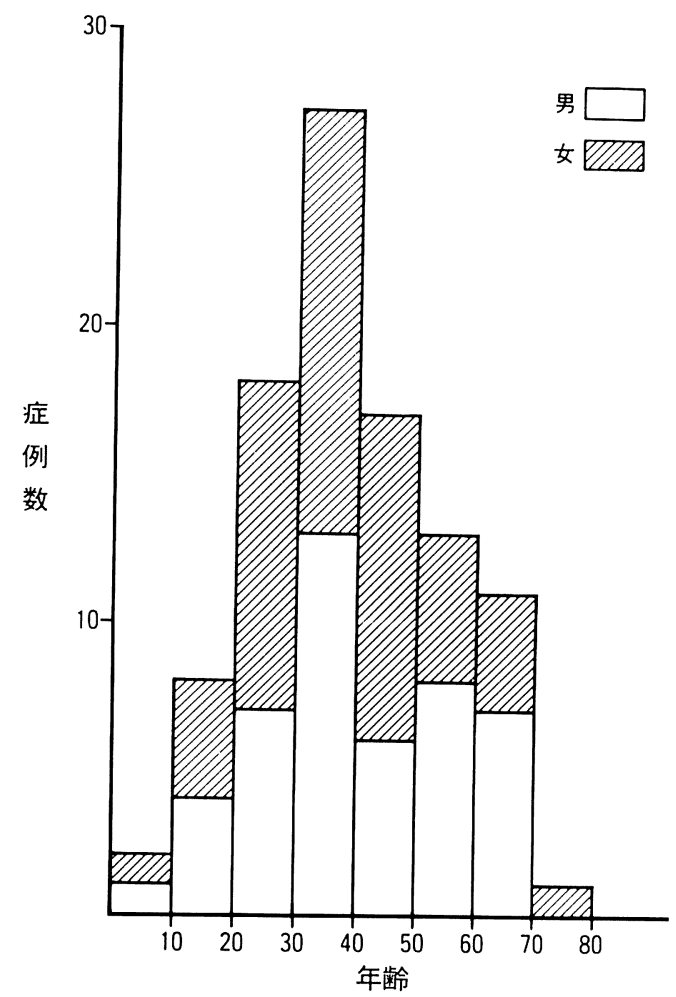

図 1 年跲と性別
例 (18.6\%), 山型 5 例 (5.2\%), 谷型 2 例 (2.1 $\%)$ の順である.聴力型の分類は, 低音域 $(250 \mathrm{H}$ $z, 500 \mathrm{~Hz}$ の平均聴力レベル) と高音域 $(4000$ $\mathrm{Hz}, 8000 \mathrm{~Hz}$ の平均聴力レベル) の差が $20 \mathrm{~dB}$ 以内を水平型, 低音域が高音域の平均聴力レベ ルに比べて $20 \mathrm{~dB}$ 以上悪い症例を低音障害型, $20 \mathrm{~dB}$ 以上良い症例を高音障害型とし, 低音域, 高音域の平均聴力レベルより中音域 $(1000 \mathrm{~Hz}$, $2000 \mathrm{~Hz}$ の平均聴力レベル）が $20 \mathrm{~dB}$ 以上高い 症例は山型, 低い症例は谷型とした。旧 JIS 聴 力損失は, 新 JIS 聴カレベルに換算した (JIS T 1201-1982).

〈治療法〉

治療は, ビタミンB群, ATP $(60 \sim 200 \mathrm{mg})$, ステロイド（ヒドロコルチゾール $\mathrm{Na}$ サクシ ネート $200 \mathrm{mg}$, ベタメタゾリン酸 $\mathrm{Na} 8 \mathrm{mg}$, メチルプレドニゾロンコハク酸 Na $250 \mathrm{mg}$, を それぞれの初回量とした）代謝促進製剤, 血管 拡張剂, 星状神経節ブロック（1〜20回）など 適宜併用した。ステロイド剂は漸減, ATP 漸 増, 点滴は, 外来通院では 1 日 1 回約 20 日, 入 院治療は，1日2回約20日連続して行い（ステ ロイド, ATP は朝 1 回のみ), 内服 (総合ビタ ミン剤, 循環改善剤, ATP)は, 毎食後約 2 力 月間行った。ビタミン B 群及びステロイド剤は 全例に，代謝製剤は91例，血管拡張剤は79例に 使用した.

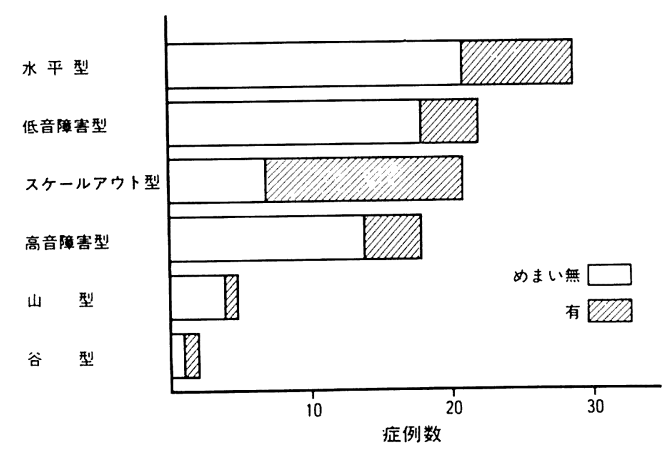

図 2 聴力型とめまいの有無 


\section{解析方法}

発症後の病日は発症当日を第 1 病日とした。 $1 \sim 7$ 病日 ( 1 週)の各音域別の平均聴力を $\mathrm{x}_{1}$, $8 \sim 10$ 病日 (1.5週)を $\mathrm{x}_{2}, 11 \sim 14$ 病日 ( 2 週) を $\mathrm{x}_{3}, 15 \sim 17$ 病日 $\left(2.5\right.$ 週) $\mathrm{x}_{4}, 18 \sim 21$ 病日 ( 3 週) $\mathrm{x}_{5}, 22 \sim 28$ 病日（ 4 週） $\mathrm{x}_{6}, 29 \sim 42$ 病 日 ( 6 週) $\mathrm{x}_{7}, 43 \sim 56$ 病日 ( 8 週) の聴力を $\mathrm{x}_{8}$ として，発症後の経過を分けた（表 1 ）。各純 音聴力とは, 初診時以外は最終病日にもっとも 近い，例えば $8 \mathrm{w}$ であれば56病日に最も近い病 日の聴力を $\mathrm{x}_{8}$ とした。聴力は低音域, 中音域, 高音域の平均聴力レベルについて検討した. 固 定時聴力（ $\mathrm{Y} ）$ は， $\mathrm{x}_{8}$ とした. $8 \mathrm{w}$ 以前に厚生 省突発性難聴研究班（1974年）の判定基準で治 癒（全治）に達した症例は， $8 \mathrm{w} に$ に最も近い最 終検査值を固定時聴力として使用した.

97例全例についての検討（T群）のほか，少 なくともひとつの周波数で $90 \mathrm{~dB}$ 未満の聴力を 示す $\mathrm{A}$ 群 (76例), 初診時聴力レベルが全ての 周波数で $90 \mathrm{~dB}$ 以上のスケールアウト型を $\mathrm{B}$ 群

表 1 発症後の経過と聴力の関係

\begin{tabular}{c|c|c}
\hline \hline 病日 & 週による分類 & 聴力 \\
\hline $1 \sim 7$ & 1 週 & $\mathrm{X}_{1}$ \\
$8 \sim 10$ & 1.5 週 & $\mathrm{X}_{2}$ \\
$11 \sim 14$ & 2 週 & $\mathrm{X}_{3}$ \\
$15 \sim 17$ & 2.5 週 & $\mathrm{X}_{4}$ \\
$18 \sim 21$ & 3 週 & $\mathrm{X}_{5}$ \\
$22 \sim 28$ & 4 週 & $\mathrm{X}_{6}$ \\
$29 \sim 42$ & 6 週 & $\mathrm{X}_{\bar{i}}$ \\
$43 \sim 56$ & 8 週 & $\mathrm{X}_{8}$
\end{tabular}

表 2 検討対象の分類

\begin{tabular}{c|c|c}
\hline \hline 群分類 & 対象症例 & 症例数 \\
\hline T群 & 全 例 & 97 例 \\
A 群 & スケールアウト型を除外したもの & 76 例 \\
B 群 & スケールアウト型 & 21 例 \\
C 群 & 低音障害型 & 22 例 \\
D群 & 高音障害型 & 18 例
\end{tabular}

(21例), 初診時聴力が低音障害型のC 群 (22例), 初診時聴力が高音障害型の D 群（18例）につい ても個別に検討した（表 2 ). 尚, 聴力がスケー ルアウトの場合 $250 \mathrm{~Hz}$ は $90 \mathrm{~dB}, 500,1000$, $2000,4000 \mathrm{~Hz}$ は $110 \mathrm{~dB}, 8000 \mathrm{~Hz}$ は $95 \mathrm{~dB}$ と して計算した。

推計学的処理は多変量解析の重回帰式による。 次に示す式により, $\mathrm{n}$ が $1 \sim 7$ までの重回㷌分 析を行い, 各々の重相関係数, 決定係数を計算 した.

式 $1 \quad \mathrm{Y}=\mathrm{Cn}+\sum_{\mathrm{i}=1}^{\mathrm{i}=\mathrm{n}} \mathrm{a}_{\mathrm{i}} \mathrm{x}_{\mathrm{i}}$

但し

$\mathrm{Y}: \mathrm{x}_{\mathrm{n}}$ まで経過したとき， $\mathrm{x}_{1} \sim \mathrm{x}_{\mathrm{n}}$ までの 聴力レベルを用いて予想される $\mathrm{n}$ 週の 聴力

$\mathrm{Cn}$ : 同条件下の回帰式の定数項

$\mathrm{a}_{\mathrm{i}}$ : xi の回㷌係数

$\mathrm{x}_{\mathrm{i}}:$ 前述の聴力

\section{結果}

1) 表 3 に低音域聴力レベルの T群解析例 （97例）を示した。低音域の定数 Cn，回㷌係 数 $\mathrm{a}_{\mathrm{i}}$, 重相関係数 (multiple coefficient), 決定 係数 (coefficient of determination) を示した. 同様な解析を中音域，高音域について行った。 さらに $\mathrm{A}$ 群， $\mathrm{B}$ 群， C 群，D群に分けてそれぞ れ低，中，高音域について解析した。結果は表 4 にまとめた。

2 ）表 4 の如くして求めた低音域，中音域, 高音域のそれぞれの群の決定係数と発症病日と の関係を, T群の久代表例として図 3 に示した。 横軸は発症病日，縦軸は決定係数を示す。

\section{考察}

1 ）対象症例に関して，突難は男性に多いと する報告が多くを占めているが定説はな (6)10)1220121)。当科では，女性に多いが有意差 は認めなかった，予後についても性差は認めら れなかった．性差により予後が異なるといら報 告もない．年柃分布では30 40歳が最も多く諸 家の報告と同様である. 
メマイの有無は予後を推定する上で重要な要 因と考兄られている。諸家の報告は, 多少のば らつきはあるものの拈拈よそ30～60\%の症例に 初診時メマイを示すものが多く, 著者らの症例 の, 33.0\%とほぼ一致している20121).

聴力型では, 水平障害型が最も多く, 低音障 害型, スケールアウト型, 高音障害型, 山型, 谷型の順で諸家の報告と一致している.

予後を推定する要因としてメマイの有無, 聴 力型の他に聴力低下の程度も重要であるとされ ている. 野村らは, 稩型と非稩型の固定時聴力 の検討より初診時聴力が異なる $2 つ の$ 群で, 予 後の聴力も全く異なる群を形成すると述べ, 竟 型と非襲型は，区別して検討したほらがよいと した26)。神崎らは29), 治療経過から初診時聴力 が $90 \mathrm{~dB}$ 以上を境にして回復の立ち上がり日数
に遅れがでることを述べ, 村橋ら ${ }^{3)}$ と, 中村ら ${ }^{17)}$ は, $90 \mathrm{~dB}$ 以上の高度難聴症例は予後不良であ ったと述べている，そこで今回我々は，97例全 例の T群と, 初診時聴力が $90 \mathrm{~dB}$ 末満の $\mathrm{A}$ 群, 初診時聴力が $90 \mathrm{~dB}$ 以上の $\mathrm{B}$ 群, 低音障害型の

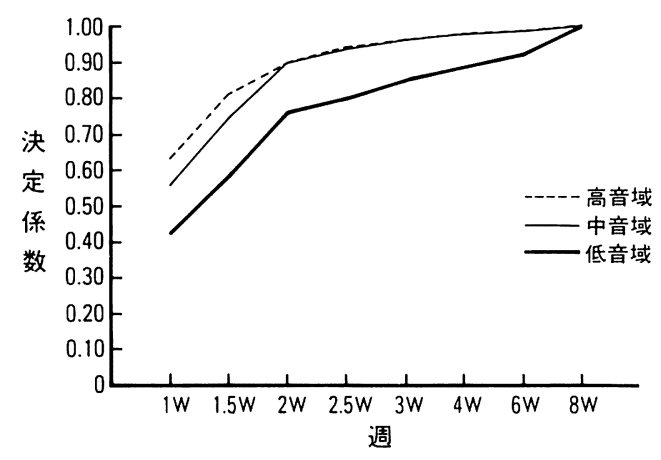

図 3 突発性難聴新鮮例の予後の推定（T群）

表 3 突発性難聴新鮮例の予後推定 T群（97例）低音部の検討

\begin{tabular}{rrrrrrrrrrr}
\hline \hline $\mathrm{n}$ & \multicolumn{1}{c}{$\mathrm{C} n$} & \multicolumn{1}{c}{$\mathrm{a}_{1}$} & \multicolumn{1}{c}{$\mathrm{a}_{2}$} & \multicolumn{1}{c}{$\mathrm{a}_{3}$} & \multicolumn{1}{c}{$\mathrm{a}_{4}$} & \multicolumn{1}{c}{$\mathrm{a}_{5}$} & $\mathrm{a}_{6}$ & $\mathrm{a}_{7}$ & 重相関 & 決定 \\
\hline 1 & -26.970 & 0.911 & & & & & & & 0.650 & 0.422 \\
2 & -9.243 & 0.115 & 0.693 & & & & & & 0.763 & 0.582 \\
3 & 3.107 & 0.017 & -0.266 & 1.029 & & & & & 0.872 & 0.761 \\
4 & 3.962 & 0.009 & -0.098 & -0.175 & 1.052 & & & & 0.897 & 0.804 \\
5 & 5.237 & -0.030 & 0.001 & -0.045 & -0.571 & 1.453 & & & 0.925 & 0.855 \\
6 & 6.992 & -0.033 & -0.093 & 0.034 & -0.196 & -0.023 & 1.139 & & 0.943 & 0.890 \\
7 & 5.824 & -0.044 & -0.105 & 0.174 & -0.259 & 0.129 & 0.091 & 0.907 & 0.962 & 0.926
\end{tabular}

表 4 突発性難聴新鮮例予後推定の決定係数

\begin{tabular}{|c|c|c|c|c|c|c|c|c|c|c|c|c|c|c|c|}
\hline \multirow[b]{2}{*}{$n$} & \multicolumn{2}{|r|}{ 低 } & \multicolumn{3}{|c|}{ 部 } & \multicolumn{5}{|c|}{ 中 } & \multicolumn{5}{|c|}{ 高 } \\
\hline & T群 & A群 & B群 & C群 & D群 & T群 & A 群 & B群 & C群 & D群 & T群 & A群 & B群 & C群 & D群 \\
\hline 1 & 0.422 & 0.210 & 0.627 & 0.271 & 0.030 & 0.555 & 0.277 & 0.463 & 0.302 & 0.06 & 0.631 & 0.696 & 0.294 & 0.379 & 0.592 \\
\hline 2 & 0.582 & 0.393 & 0.706 & 0.409 & 0.275 & 0.748 & 0.586 & 0.706 & 0.651 & 0.623 & 0.815 & 0.737 & 0.825 & 0.672 & 0.721 \\
\hline 3 & 0.761 & 0.655 & 0.716 & 0.783 & 0.457 & 0.902 & 0.867 & 0.882 & 0.897 & 0.867 & 0.894 & 0.859 & 0.861 & 0.862 & 0.875 \\
\hline 4 & 0.804 & 0.720 & 0.739 & 0.880 & 0.482 & 0.938 & 0.907 & 0.884 & 0.910 & 0.941 & 0.946 & 0.920 & 0.943 & 0.939 & 0.948 \\
\hline 5 & 0.855 & 0.789 & 0.764 & 0.970 & 0.862 & 0.965 & 0.946 & 0.925 & 0.983 & 0.972 & 0.963 & 0.952 & 0.949 & 0.962 & 0.963 \\
\hline 6 & 0.890 & 0.827 & 0.881 & 0.992 & 0.937 & 0.983 & 0.970 & 0.961 & 0.992 & 0.981 & 0.985 & 0.978 & 0.989 & 0.975 & 0.990 \\
\hline 7 & 0.926 & 0.875 & 0.985 & 0.996 & 0.941 & 0.991 & 0.994 & 0.979 & 0.999 & 0.998 & 0.990 & 0.984 & 0.995 & 0.979 & 0.994 \\
\hline
\end{tabular}


C 群, 高音障害型の D群に分けて検討した。

新鮮例とは，いつまでを言らのかの定義はな く, 発症 3 日まで, 発症 7 日まで，発症 2 週ま でとするなど報告者により異なる1)2123). 今回我 我が発症 7 日以内に治療を開始した症例を新鮮 例とした理由は，以下の如くである。者田ら ${ }^{12)}$ は, 全治, 略治が発症後 7 日以内に治療を開始 した症例に有意に多いことより，7日あたりに も critical point を考えてもよいのではと述べ ている．神崎ら29) は 1 週間目の改善率が予後 の指標と成り得るとしている. 設楽ら30)31) は, 周波数別回復性の検討より，発症後 1 週間以上 経て来院した症例では，固定時聴力の密集の程 度がややあいまいになると述べている，柳田 ら16) は, 突発性難聴初診後の悪化例の検討よ り，難聴が maximum になるのは発症 8 日まで でそれ以降に悪化したものはなかったといら結 果を示している．また宮崎ら帛は，蝸牛障害の 拡大の結果生じると考えられるメマイ随伴症例 の眼振方向の検討により，発病から7日以内は 患側向きの眼振を認める症例が多く，8 日以後 になると健側向きが多いと報告している。これ らの報告を総括すると，7日頃には何らかの point があると考えるのが妥当と思われる。 ま た発症後 1 週間以内に受診する割合が多いのも 一つの理由である。以上の様な報告に基ついて 新鮮例を発症 7 日までとした。

固定時聴力に関しての定義も現時点では明確 なものはない27)。諸家の報告では， ほぼ一致し て一カ月を経過すると汇とんどの症例は固定す るといわれている.八木らは約 $2 \sim 3$ 週で固定 する2), 中村17) や立木22), 神崎ら ${ }^{28)}$ は約 4 週〜 1 力月で固定する，小田ら ${ }^{11)}$ は非新鮮例につ いて検討し，治療開始までに 7 週以上経過して いる症例では $90 \%$ 以上の症例が固定していると 述べている. また原田らは回復過程の検討より, 15 日以内の早期回復型と 30 日以上の経過で聴力 が回復してくる晚期回復型, その中間型に分類 している13)。多幾山ら ${ }^{10)} は$, 最も早期に固定し た症例は 1 日であり，全体の $58.5 \%$ が 2 週間以
内に固定，最長例は，59日間を要したと報告し ている。このよらな報告を考慮して，できるだ 壮固定時を長く設定し 8 週とした。なお，当科 での投薬期間も約 8 週でその期間聴力の経過を 追跡し得た症例が多いことも8週とした理由に 含まれている。

2）解析法に関して, 筆者らは初診時から経 過病日までの聴力レベルの結果を用いて固定時 聴力を推定する試みを行った，各々経過病日に おいて固定時聴力をどれくらい確かに推定でき るか, すなわち式 1 による推定がどのくらい確 かかを知るため決定係数がどれくらいであるか を検討した。

例えば, 式 1 に於いて $\mathrm{n}=4$ すなわち2.5週 経過したときそれまでに得られた聴力 $\mathrm{x}_{1} \sim \mathrm{X}_{4}$ の聴力を用いて $\mathrm{Y}$ (固定時聴力 $\mathrm{x}_{8}$ ) が推定で き，この時の重回帰分析の決定係数を知ればど のくらいの確かさでYが推定可能であるかが解 る。例えばT群の低音域の 2.5 週経過したとき の検討では, 以下の式で示されるように

$$
\begin{aligned}
\mathrm{Y}= & 3.962+0.009 \mathrm{x}_{1}+(-0.098) \\
& \mathrm{x}_{2}+(-0.175) \mathrm{x}_{3}+1.052 \mathrm{x}_{4}
\end{aligned}
$$

で固定時聴力 $\mathrm{Y}(\mathrm{dB})$ が推定できる.この場合 の決定係数は，0.804となる（表 3 ).

3 ）得られた成績に関して, 表 4 , 図 3 より 全症例の T群に於て, 決定係数 0.8 以上の確か さで予後が推定できる時期を見ると，低音域は 2.5 週, 中音域は 2 週, 高音域は 1.5 週までの恥 力で固定時恥力が推定出来る事となる. 同様に 表 4 より $\mathrm{A}$ 群に於て低音域は 4 週，中音域は 2

表 5 決定係数 0.8 以上に必要な期間

\begin{tabular}{c|c|c|c}
\hline \hline & 低音域 & 中音域 & 高音域 \\
\hline (T群) & 2.5 週* & 2 週* & 1.5 週* \\
(A群) & 4 週* & 2 週* & 2 週 \\
(B群) & 4 週 & 2 週 & 1.5 週* \\
(C群) & 2.5 週 & 2 週 & 2 週 \\
(D群) & 3 週 & 2 週 & 2 週
\end{tabular}


週，高音域は 2 週，また B 群では低音域は 4 週， 中音域は 2 週, 高音域は 1.5 週, C群では低音 域は2.5週, 中音域は 2 週, 高音域は 2 週, D 群ではそれぞれ 3 週, 2 週, 2 週となる（表 5 ). 固定時聴力レベルを予想するのに, 発症後早期 に推定可能であるといらことは，言い換えれば 固定に要する期間が短いと言える。ただし回復 の程度は別である. 反対に, 推定に時間を要す る場合, 聴力固定に要する時間が長く, 長期に わたって変動することを意味する. 聴力型の如 何に関わらず，低音域は変動し易く固定時聴力 を推定するのに時間を要する。逆に, 高音域は 变動しにくく早期に推定可能である. その差は $0.5 \sim 1.5$ 週である. 中音域は, 注ぼその中間で ある. 柳田, 村橋3)14) は, 聴力の回復は周波数 によって多少異なり，低音域は高音域に比べて 1 週間遅くまで改善し, 聴力の改善の程度も良 好であるといら。そのためか, 固定時のオージ オグラムの型は症例の約 $40 \%$ が高音障害型を呈 すると述べており，今回の報告と一致している. また, 設楽, 岡本らも同様な意見として, 周波 数により回復性は異なり周波数が高くなるに従 い回復の悪い症例が増加すると述べている29330). 今回の結果から, 初診時聴力のみでの固定時聴 力の推定で, $\mathrm{T}$ 群の低音域の決定係数は 0.422 , 中音域は 0.277 , 高音域 0.631 で, 発症後 4 週ま での聴力より推定すると, 低音域 0.890 , 中音 域 0.970 , 高音域 0.985 の確かさで予後の推定が 可能である. 柳田314) は, $5 \sim 7$ 病日の聴力損 失から固定時聴力を予想する場合これだけで決 定係数 0.521 で推定できるとし, さらに高〜低 音差の因子を加えると0.557, 前庭症状の有無 を加えると約 $60 \%$ 推定可能で， $3 \sim 4$ 週経過す

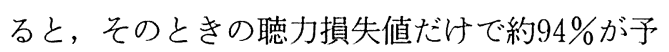
想されるとし，突難の予後を推定するに当たっ て, その「病日」での「聴力損失の程度」を最 も重視すべきであり，そのほかの要因を合わせ ることにより, さらに確実性が増すと述べてい る. 今回我々は柳田の言う, その「病日」だけ ではなく，その「病日まで」の「それぞれの聴
カレベルの程度」を用いて予後の推定を行った が, 高低差や前庭症状を加えれば更に確かな推 定が可能であるかさらに検討したい。

\section{まとめ}

7 日以内に当科を受診し加療した突難新鮮例 に対し, 重回帰分析により予後の推定をした.

1 ）初診時聴力に関係なく低音域は回復期間 が長く, 予後の推定に長期観察を必要とする.

2 ）初診時聴力に関係なく, 低音, 中音, 高 音と周波数が高くなるほど予後の推定は早期に 可能である.

本論文の要旨は第91回日本耳鼻咽喉科学会総会 （1990, 5, 17-5, 19 東京）において発表した。

\section{参考文献}

1）太田文彦, 文珠敏郎, 三好豊二: 突発性難聴新 鮮例の検討. 耳鼾臨床 $61: 195 \sim 200,1968$.

2) 八木聡明, 加賀 宏, 鈴木淳一: 突発難聴新鮮 例の検討. 耳喉 $52: 205 \sim 211,1980$.

3）村橋けい子, 柳田則行 : 突発性難聴の予後の推 定に関する研究. 日耳鼻 85：926〜940， 1982.

4）柳田則行, 鈴木康之, 村橋けい子, 他 : 突発性 難聴 scale out 症例の予後と病態. 耳鼻臨床 $75: 769 \sim 778, \quad 1982$.

5) Schnknecht H F, Benitez J, Beekhuis J, et al : The pathology of sudden deafness. Laryngoscope $72: 1142 \sim 1157,1962$.

6) Schuknecht H F, Kimura R S and Naufal P M : The pathology of sudden deafness. Acta Otolaryngol (Stockh) $76: 75 \sim 97,1973$.

7）三宅 弘, 柳田則之, 勝見清子 : 突発性難聴の 成因説之治療法一各国の現状調查報告一, 耳鼻 $24: 1 \sim 11, \quad 1987$.

8）瀧口哲也, 大尾嘉宏巳, 西部 聡, 他: 当科に 捄故る突発性難聴患者の最近の 10 年間の統計的 観察. 耳展 $29: 53 \sim 58,1986$.

9）宮崎為夫, 瀧口哲也, 大尾嘉宏巳, 他 : めまい 老伴万突発性難聴の統計的観察. 耳鼻臨床 80 : 715 721, 1987.

10）多幾山礼子, 竹吉 悟, 津野信輔, 他: 突発難 聴106例の検討. 麻酔之蘇生： $23: 263 \sim 273$, 1987. 
11）小田恂, 小松崎篤, 長船宏隆, 他: 非新鮮例 突発性難聴について。臨床耳科 14：208～209, 1987.

12）太田文彦：突発性難聴. 日獨医報 19：447〜 $471, \quad 1974$.

13）原田勇彦，鈴木光也，横山正人，他：突発性難 聴に扣ける回復過程の検討一聴力回復例を中心 として一. 急性高度難聴調查研究班昭和 61 年度 研究業績報告書. $163 \sim 165 ， 1986$.

14）柳田則之，村橋けい子：突発性難聴の臨床。日 本医事新報 $3250: 15 \sim 18,1986$.

15）柳田則之：突発性難聴の臨床一病因, 治療, 予 後に関する最近の知見一。耳鼻臨床 $78: 299$ $311,1985$.

16）柳田則之, 鈴木康之, 村橋けい子, 他：突発性 難聴初診後の悪化例. 臨床耳科 $10: 212 \sim 213$, 1983.

17）中村興治, 寺山吉彦, 山地誠一, 他 : 突発性難 聴の自然治癒例と治瘉例との比較. 日耳鼻 84 : 983 998, 1981.

18）村田清高: 高圧酸素が内耳に及ぼす影響に関す 万電気生理学的研究. 耳鼻臨床 $66: 1077$ $1104,1973$.

19）岸本誠司, 齋藤春雄, 森本正紀, 他 : 内耳出血 による突発性難聴一側頭骨所見一。耳鼾 21 : $589 \sim 593, \quad 1975$.

20）田中耕一, 岡本了, 桧 緑, 他：過去 6 年間 の突発性難聴の統計的観察一特に眩暈の有無に ついて一.耳鼻臨床 $72: 1203 \sim 1210 ， 1979$.

21）和田 淳, 大山健二, 沖津卓二, 他 : 当教室に おける突発性難聴症例の分析. 耳鼻 $25: 169$ $173, \quad 1979$

22）立木 孝, 村井和夫, 宍戸 潔, 他 : 突発性難 聴の再検討一特に高度難聴例について。臨床耳
科 $8: 208 \sim 209, \quad 1981$.

23）佐藤恒正：突発性難聴新鮮例の検討. 耳喉 52 : $205 \sim 211 ， 1980$.

24）柳原弘男：実験的正円空膜破裂の聴覚生理学的 組織学的研究.耳鼻臨床 $76: 1453 \sim 1473 ， 1983$.

25）岸本昭憲, 中田将風：突発性難聴に対する高気 圧酸素療法の統計的観察. 耳鼻臨床 11：162～ 163, 1984.

26）野村恭也，小田 恂，林田哲朗，他：万弓型突 発性難聴の予後. 厚生省特定疾患急性高度難聴 調査研究班 昭和61年度研究報告書. 95 100, 1986.

27）大橋正寛, 寺山吉彦, 佐藤信清, 他 : 突発性難 聴の予後判定基準の再検討。日耳鼻 $89: 1848$ $\sim 1854, \quad 1986$.

28）神埼 仁, 猪 忠彦, 高橋正紘, 他 : 突発性難 聴新鮮例の聴力回復と蝸電図所見.耳鼻臨床 $68: 639 \sim 646, \quad 1975$.

29）神埼 亿, 小川茂雄, 小川 郁 : 突発性難聴の 治療経過．急性高度難聴調査研究班昭和63年度 研究業績報告書. 139 141， 1988.

30）設楽哲也，岡本牧人：突発性難聴の周波数別回 復性の検討その 2 . 厚生省特定疾患急性高度難 聴調査研究班昭和 62 年度研究業績報告書. 137 $\sim 140,1987$.

31）設楽哲也，岡本牧人：突発性難聴の周波数別回 復性の検討々の 3 . 厚生省特定疾患急性高度難 聴調査研究班昭和 62 年度研究業績報告書. 141 $\sim 142, \quad 1987$.

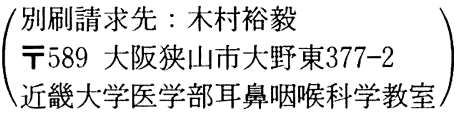

